\title{
Correlation between social support and the achievement of the development of self-concept to deaf children $7-12$ years
}

\author{
Siti Nurmalasari, Tantut Susanto, ${ }^{*}$ Kholid Rosyidi Muhammad Nur \\ Department of family and community health nursing, Faculty of Nursing, University of Jember, Jember, Indonesia
}

KEYWORDS
Social support
Self-concept
Deaf children
Child development
Disability
communication

SUBMITTED: 24 April 2019

REVISED: 10 April 2020

ACCEPTED: 19 May 2020

\begin{abstract}
Children with deaf have a disability in language and communication because they cannot hear and understand their environment, so that is not uncommon for people around them to assume that children with deaf cannot live in the social environment. This matter shows the community to deaf children where it can affect children's self-concept with the deaf. This research aims to analyze the correlations between social support and self-concept in children with the deaf. A cross-sectional study was used to examine 51 children with deaf 7 - 12 years selected with a convenience sampling method. The questionnaire consisted of identity data used to measure participant characteristics. Social Support Questionnaire for children (SSQC) was used to measure social support and the Self-Description Questionnaire to measure self-concept. The Chi-Square test is used to answer the objectives of this study. From 51 respondents, $44(86.3 \%)$ deaf children received good social support, with the most social support obtained from 36 friends $(70.6 \%)$ and siblings 36 (70.6\%). Of the five components of social support, only social support from friends and siblings most resulted in low-deaf children's self-concept. There was a relationship between social support and the self-concept of deaf children $(Z=1.833 ; p$-value $=0.034)$. Support from various sources is needed for deaf children to develop self-concept in their social life. Therefore, the child's social environment needs to provide adequate social support for developing an excellent deaf child's self-concept.
\end{abstract}

(c) The Journal 2020. This article is distributed under a Creative Commons Attribution-ShareAlike 4.0 International license.

\section{Introduction}

Deafness is someone who has a hearing disorder or cannot hear. Deafness can be divided into two categories, namely deafness and hard hearing. Deafness is when someone has severe hearing damage so that their hearing can no longer function properly. Someone is deaf if the degree of hearing loss is $90 \mathrm{~dB}$ (profound). Meanwhile, hearing loss is someone whose sense of hearing is damaged but can still hear, whether using a hearing aid or not. A person is said to be hearing impaired if the degree of hearing impairment is $27-40 \mathrm{~dB}$ (mild), $41-55 \mathrm{~dB}$ (moderate), $71-90 \mathrm{~dB}$ (severe). ${ }^{1}$

In connection with hearing impairment, children with hearing impairment often have a low selfconcept. Self-concept is how a person views himself,

\footnotetext{
*Correspondence: tantut_s.psik@unej.ac.id

Departement of family and community health nursing, Faculty of Nursing, University of Jember, Jl. Kalimantan 37 Jember, Jawa Timur 68121
}

which is about a child's self-concept in academic and non-academic fields. Deaf children can also have a negative self-concept if they have low scores on general school indicators, general self, mathematics, reading, and peer relationships. ${ }^{2}$ This can happen because children with hearing impairment cannot hear and understand their surroundings like normal children. They have language limitations that can interfere with communication with their social environment. ${ }^{3}$ Self-concept is learned partly through social contact and experiences with other people over time. This condition is called "learning about oneself from another person's mirror." A person's self-concept lies in what he thinks about other people who think about him. Another person that matters to young children is the parent who helps the child grow and react to experiences. ${ }^{4}$

The prevalence of deafness in developed countries aged 0 - 59 years is $7.4 \%$ and those aged 60 years and over $18.5 \%$. For developing countries, at the age of $0-59$ years are about $54.3 \%$ and those 
over 60 years old are $43.9 \%$. So, the total prevalence of hearing impairment in the world is $124.2 \% .^{5}$ In the 2011 Social Protection Program Data Collection (Pendataan Program Perlindungan Sosial), there were 3861 children with hearing impairment. ${ }^{6}$ Meanwhile, the number of deaf people attending school in Indonesia is 5,852 students. In addition, for East Java province itself, the number of deaf people attending school is 103 students. $^{7}$ Especially, in Jember Regency, 666 children with hearing impairment attend special schools. ${ }^{8}$

The low level of public understanding of disability causes disability to be underestimated in the community. The community considers that having children with disabilities is a disgrace for the family, so parents or families have to hide the children in the house. This perception shows the lack of social support from the broader community for persons with disabilities, including deaf children. So that not a few deaf children think that they do not deserve to be in society. It also causes the selfconcept of deaf children to be disturbed because of the low social support provided. ${ }^{6}$

Deaf children certainly do not only live in their families but also live in the community. Children with a hearing impairment must adapt based on developing skills and needs and adapt to the developing environment's pressure. Children with hearing impairment are often faced with the additional challenge of managing adaptations to society because of their limited communication. The responses given by the community are positive, and some are negative. It can affect the self-concept of deaf children because the community response shows how much social support is given to deaf children. ${ }^{9}$ Because of these obstacles, children with a hearing impairment, needs support in the form of encouragement either directly or indirectly from the closest people..$^{10}$ Social support is needed so that an individual who is deaf can control his emotions and feelings. ${ }^{10}$ It can be assessed by looking at the social relationships of deaf children with parents, siblings, and peers and how deaf children see themselves, their psychological development, and their physical and learning abilities. ${ }^{2,11}$ The social support provided can be in the form of emotional support, instrumental support, information support, and assessment support. The social support provided comes from parents, siblings (brother/sister), siblings, peers, and people closest to the child, such as teachers. ${ }^{11}$

From the explanation of the phenomenon above, it is necessary to conduct research related to the relationship between social support and the selfconcept of deaf children to assess how much social support can affect the development of children's self-concept with hearing impairment.

\section{Method}

This study used a cross-sectional design. In this study, 51 respondents were selected from 55 deaf students who have age 7-12 years old in five special schools in Jember Regency. It was including SLB (Sekolah Luar Biasa)-B TPA and Autism Bintoro, SLBN Jember, SLB BCD YPAC, SLB ABC Balung, and SLB IT Daarut Tarbiyat Ummah using convenience sampling. The sample chosen was a sample that met the inclusion and exclusion criteria of the study. The inclusion criteria were deaf children aged 7-12 years, willing to be respondents, and understand sign language. The exclusion criteria were children with hearing impairment who did not have a guardian, single child, or not having siblings, not being at the research location at the time of the research, and withdrew from school.

Initially, the researcher conveyed the aims and objectives of the research to the school (teacher). After the school agreed to carry out the research, the researchers conducted a perception equation with the teacher to understand the questionnaire's filling process. Deaf students will fill in the questionnaire. They will be accompanied and guided by the teacher using sign language to make it easier for them to understand and answer the questionnaire. Researchers also made informational concentrations that would later be distributed to prospective respondents and approved by their parents. Based on that consent information, data was obtained as many as 3 students were the only child in their family. Moreover, based on the school's information, one student had not visited the school for a long time, so he was not in the research location when the research was conducted. The study's total respondents were 51 deaf children aged 7-12 years 
in special schools in Jember Regency.

This study's data collection tool was the SSQC (Social Support Questionnaire for Children) ${ }^{11}$ to measure social support for deaf children consisting of 50 questions. It consists of five social support sources such as parental social support, sibling social support, social support from adults, social support from friends, and social support for siblings. The calculation of the final results of the questionnaire used a cutoff point value (the total 99.5), namely parents' social support with a cutoff point value of 20 , social support with a cutoff point value of 16 , adult social support with a cutoff point of 20 , social support from friends with a cutoff point of 17.5, and social support for brother/sister with a cutoff point value of 34.5. Each question will be assessed with a Likert scale from 0 to 4 , with the criteria never (0), sometimes (1), often (2), always (3), and cannot be applied (4). The questionnaire used to measure selfconcept is the SDQ (Self Description Questionnaire) questionnaire by Spring, which adapts from SDQ-I by Marsh. ${ }^{2}$ The questionnaire consists of 42 questions with the final result using a cutoff point value obtained by 63 . Each question will be assessed on a Likert scale, namely a scale of $0-3$, with the criteria that untrue (0), somewhat true (1), true (2), and very true (3).

Both instruments have gone through the consent validity index (CVI) test involving 10 lecturers who are experts in community nursing, pediatric nursing, and mental nursing with results for SSQC of 0.0839 and SDQ of 0.8565 . The questionnaire can be declared valid with Cronbach $\alpha$ values ranging from 0.63 to 0.77 . Then the researchers conducted a reliability test on 51 respondents in five special schools in Jember district who had been selected as research sites with Alpha Cronbach value. The total of social support $=0.940$, parent social support $=0.926$, sibling social support $=0.908$, adult social support $=0.910$, brother $/$ sister social support $=0.861$, peer social support $=0.859$. Meanwhile, the reliability value of the SDQ is 0.912 . So, the SSQC and SDQ questionnaires can be said to be valid and reliable.

Procedures related to data collection techniques in this study, namely the researcher submitting a permit application letter through the academic section to the Dean of the Faculty of Nursing, University of Jember addressed to LP2M University of Jember for introduction to the National and Political Unity Agency of Jember, SLB-B TPA and Autism Bintoro, SLBN Jember, SLB BCD YPAC, SLB ABC Balung, and SLB IT Daarut Tarbiyah Ummah. After permitting the school, the researchers coordinated and shared perceptions with the teachers of each class regarding the questionnaire that would be distributed to be filled in by deaf students aged 7-12 years as research respondents.

Before filling out the questionnaire, the researcher distributed informants about potential respondents approved by the respondents' parents. If the parents agree to the consent information, and the child meets the research criteria, they would become a research respondent. After finding the number of respondents who would be used as research respondents, the researchers were accompanied by their respective class teachers to share information with the respondents.

The respondent's inform consent contains the name, age, gender, education (class of children), type of disability, and the length of time suffering from hearing loss. After that, the researcher distributed a social support questionnaire (Social Support Questionnaire for Children) and a self-concept questionnaire (Self-Description Questionnaire). The respondents filled out the questionnaire assisted by the class teacher to translate and explain sign language for deaf students who could not read and for deaf students who could read filled out the questionnaire independently, accompanied by the researcher as a facilitator. Before the research was concluded, the researcher would like to thank the respondents who had been willing to participate in the research from beginning to end.

Data analysis in this study was carried out using SPSS Statistics software 16, for univariate analysis of categorical data used frequency distribution with percentage size. Meanwhile, numerical data with abnormal distribution have presented the median, 25-75 percentile, $t$-value, and $p$-value using the OneSample Test while bivariate data analysis using the Chi-Square test. In addition, nursing research using human subjects must understand ethical principles 
or research ethics. Research on the relationship of social support with the achievement of self-concept development of children with hearing impairment aged 7-12 years has been conducted an ethical test at the Faculty of Dentistry, University of Jember with the ethical number 295 / UN25.8 / KEPK / DL / 2019.

\section{Result}

Based on the 51 respondents, the characteristics of deaf children aged 7-12 years in special schools in Jember district were compiled. The age of the participants had a median value of 11 years, the majority of whom attended special schools in

Table 1. Distribution of Respondent Characteristics ( $\mathrm{n}=$ 51)

\begin{tabular}{|c|c|}
\hline Respondent characteristics & $\mathbf{N}(\%)$ \\
\hline \multicolumn{2}{|l|}{ Age (year) } \\
\hline $\mathrm{Md}(\mathrm{P} 25-\mathrm{P} 75)$ & $11(9-12)$ \\
\hline \multicolumn{2}{|l|}{ School } \\
\hline SLBN & $15(29,4)$ \\
\hline SLB Bintoro & $23(45,1)$ \\
\hline SDLB BCD YPAC & $7(13,7)$ \\
\hline SLB ABC Balung & $5(9,8)$ \\
\hline SLB IT DTU Kalisat & $1(2)$ \\
\hline \multicolumn{2}{|l|}{ Type of deafness } \\
\hline \multicolumn{2}{|l|}{ Deafness } \\
\hline Mild & $10(19,6)$ \\
\hline Moderate & $10(19,6)$ \\
\hline Severe & $19(37,3)$ \\
\hline \multicolumn{2}{|l|}{ Hard hearing } \\
\hline Profound & $12(23,5)$ \\
\hline \multicolumn{2}{|c|}{ Length of suffering from deafness } \\
\hline Pregnancy & $3(5,9)$ \\
\hline Birth & $30(58,8)$ \\
\hline Postnatal & $18(35,3)$ \\
\hline \multicolumn{2}{|l|}{ Parent's job } \\
\hline Entrepreneur & $18(35,3)$ \\
\hline Teacher & $3(5,9)$ \\
\hline Private & $9(17,6)$ \\
\hline Farmer & $6(11,8)$ \\
\hline Civil servants & $2(3,9)$ \\
\hline Housewife & $12(23,5)$ \\
\hline Nurse & $12(23,5)$ \\
\hline \multicolumn{2}{|c|}{ Parents' Sign Language Usage History } \\
\hline Nothing & $14(27,5)$ \\
\hline Yes & $37(72,5)$ \\
\hline
\end{tabular}

Bintoro (45.1\%) with the hearing impairment, the deaf category (37.3\%), deaf from birth $(58.8 \%)$, the majority of parents work as entrepreneurs (35.3\%), and can use sign language (72.5\%). The characteristics of the respondents from this study are listed in Table 1.

Table 2 shows that the social support for deaf children aged 7-12 years in special schools in Jember Regency is very significant. The average value is 3.59 $\pm 2.140(\mathrm{t}=63.774 ; 95 \% \mathrm{Cl}=3.00-4.20)$. Based on the estimated value, deaf children aged 7-12 years in SLB Jember Regency have good social support.

Table 3 shows that the self-concept of deaf children aged 7-12 years in SLB Jember Regency is very significant with an average value of 59.82 \pm 17.229 ( $t=24.797 ; 95 \% \mathrm{Cl}=54.98$ - 64.67). The estimated value shows deaf children aged $7-12$ years in SLB Jember Regency have a low self-concept.

Table 4 shows a difference between social support and self-concept, as evidenced by the ChiSquare test $(p$-value $=0.034)$. It can be concluded that there is a relationship between social support and self-concept of deaf children aged 7-12 years in SLB Jember Regency. Deaf children with good social support had a low self-concept 1,833 times (OR $=1,833 ; 95 \% \mathrm{Cl}=1,400-2,401)$. Judging from the social support component of friends, it is related to the self-concept of children with hearing impairment ( $p$-value $=0.015)$. The deaf children with good social support from friends 6,500 times have a good selfconcept $(\mathrm{OR}=6,500 ; 95 \% \mathrm{Cl}=1.297-33.034)$. Social support for siblings is related to the self-concept of children with hearing impairment ( $p$-value $=0.015)$, namely children with hearing impairment who have good social support from siblings 6,500 times have a good self-concept $(\mathrm{OR}=6,500 ; 95 \% \mathrm{Cl}=1,297$ $33,034)$. On the other hand, there is no relationship between the social support of parents, siblings, and adults (Table 4). The self-concept of deaf children as evidenced by the results of the Chi-Square test such as parental social support ( $p$-value $=0.143)$, sibling social support ( $p$-value $=0.067$ ), adult social support $(p$-value $=0.0166)$.

\section{Discussion}

Based on the results, social support is related to 
Table 2. Distribution of social support for deaf children aged 7-12 years in Jember special schools $(n=51)$

\begin{tabular}{llllll}
\hline Social support & $\mathbf{M} \pm \mathbf{S D}$ & \multirow{2}{*}{} & $\boldsymbol{p}$-value & \multicolumn{2}{c}{ 95\% Confidence interval } \\
\cline { 5 - 6 } & & & & Min & Max \\
\hline Parent & $0.90 \pm 0.300$ & 21.448 & $<0.001^{\mathrm{a}}$ & 0.82 & 0.99 \\
Family & $0.49 \pm 0.505$ & 6.934 & $<0.001^{\mathrm{a}}$ & 0.35 & 0.63 \\
Adult & $0.78 \pm 0.415$ & 13.484 & $<0.001^{\mathrm{a}}$ & 0.67 & 0.90 \\
Friend & $0.71 \pm 0.460$ & 10.954 & $<0.001^{\mathrm{a}}$ & 0.58 & 0.84 \\
Siblings & $0.71 \pm 0.460$ & 10.954 & $<0.001^{\mathrm{a}}$ & 0.58 & 0.84 \\
Total & $3.59 \pm 2.140$ & 63.774 & $<0.001^{\mathrm{a}}$ & 3.00 & 4.20 \\
\hline
\end{tabular}

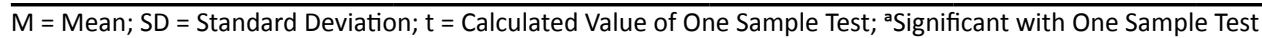

Table 3. Distribution of self-concept for deaf children aged 7-12 years in Jember special school $(n=51)$

\begin{tabular}{|c|c|c|c|c|c|}
\hline \multirow{2}{*}{ Self-concept } & \multirow{2}{*}{$M \pm S D$} & \multirow{2}{*}{$\mathbf{t}$} & \multirow{2}{*}{$p$-value } & \multicolumn{2}{|c|}{ 95\% Confidence interval } \\
\hline & & & & Min & Max \\
\hline General school & $18.98 \pm 5.093$ & 26.614 & $<0.001^{\mathrm{a}}$ & 17.55 & 20.41 \\
\hline General self & $7.12 \pm 3.907$ & 13.009 & $<0.001^{\mathrm{a}}$ & 6.02 & 8.22 \\
\hline Mathematics & $11.27 \pm 4.405$ & 18.279 & $<0.001^{\mathrm{a}}$ & 10.04 & 12.51 \\
\hline Reading & $11.86 \pm 5.875$ & 14.419 & $<0.001^{\mathrm{a}}$ & 10.21 & 13.52 \\
\hline Relationship with friendship & $10.59 \pm 3.287$ & 23.001 & $<0.001^{\mathrm{a}}$ & 9.66 & 11.51 \\
\hline Total & $59.82 \pm 17.229$ & 24.797 & $<0.001^{\mathrm{a}}$ & 54.98 & 64.67 \\
\hline
\end{tabular}

$\mathrm{M}=$ Mean; SD = Standard Deviation; $\mathrm{t}$ = Calculated Value of One-Sample Test; ${ }^{\mathrm{a}}$ Significant with One Sample Test

Table 4. The relationship between social support and the achievement of self-concept development for children with deaf children ages $7-12$ years

\begin{tabular}{|c|c|c|c|c|}
\hline \multirow[b]{2}{*}{ Social support } & \multicolumn{2}{|c|}{ Self-concept } & \multirow[b]{2}{*}{$p$-value } & \multirow{2}{*}{$\begin{array}{l}\text { OR } \\
\text { 95\% CI } \\
\text { (Lower - Upper) } \\
\end{array}$} \\
\hline & $\begin{array}{l}\text { Low } \\
\text { n (\%) }\end{array}$ & $\begin{array}{l}\text { High } \\
\text { n (\%) }\end{array}$ & & \\
\hline \multicolumn{5}{|l|}{ Parents } \\
\hline Poor & $5(16.1)$ & $0(0)$ & 0.143 & $1.769(1.373-2.280)$ \\
\hline Good & 26 (83.9) & $20(100.0)$ & & \\
\hline \multicolumn{5}{|l|}{ Family } \\
\hline Poor & $19(61.3)$ & $7(35.0)$ & 0.067 & $2.940(0.914-9.465)$ \\
\hline Good & $12(38.7)$ & $13(65.0)$ & & \\
\hline \multicolumn{5}{|l|}{ Adult } \\
\hline Poor & $9(29.0)$ & $2(10.0)$ & 0.166 & $3.682(0.704-19.247)$ \\
\hline Good & $22(71.0)$ & $18(90.0)$ & & \\
\hline \multicolumn{5}{|l|}{ Friend } \\
\hline Poor & $13(4.9)$ & $2(10.0)$ & $0.015^{\mathrm{a}}$ & $6.500(1.279-33.034)$ \\
\hline Good & $18(58.1)$ & $18(90.0)$ & & \\
\hline \multicolumn{5}{|l|}{ Siblings } \\
\hline Poor & $13(41.9)$ & $2(10.0)$ & $0.015^{\mathrm{a}}$ & $6.500(1.297-33.034)$ \\
\hline Good & $18(58.1)$ & $18(90.0)$ & & \\
\hline \multicolumn{5}{|l|}{ Total } \\
\hline Poor & $7(22.6)$ & $0(0)$ & $0.034^{\mathrm{b}}$ & $1.833(1.400-2.401)$ \\
\hline Good & $24(77.4)$ & $20(100.0)$ & & \\
\hline
\end{tabular}

Note: $\mathrm{n}(\%)=$ the number of participants (percentage); a significance is determined by Chi-Square and Fisher's Exact Test determined $\mathrm{b}$ significance; OR: $95 \%$ Cl (Lower - Upper) = Odds ratio $95 \%$ confidence interval

the self-concept of deaf children aged 7-12 years in special schools in Jember Regency. The result is in line with another research, which shows a significant correlation between different social support sources in almost all self-concept areas among students with disabilities. ${ }^{12}$ On the other hand, based on the 
research results, the relationship between social support and self-concept of children with hearing impairment is inversely related because of the five components, such as lack of social support from friends and social support for siblings is significantly related to the self-concept of children with hearing loss.

In this study, social support for deaf children aged 7-12 years in SLB Jember Regency had the best social support. The results of this study were higher than the results of previous studies. ${ }^{13}$ Most of the social support is obtained from friends and also brothers/ sisters. Social support from good friends is due to the similarities between deaf children in school so that they create communication with each other, which makes them support each other. The presence of peers can organize cooperative play to meet the quality of play of children with hearing impairment. It would help children to engage in a higher level of social play when interacting in peer groups. ${ }^{14}$

Besides social support from friends, social support for siblings to children with hearing impairment is also related to their self-concept. Children with hearing impairment spend more time with their siblings than their parents when they are at home. ${ }^{15}$ Time spent more with siblings when they are at home makes children more open to their siblings so that a sibling can know well what support should be given to their mate.

Social support from friends and social support between siblings and siblings is related to the child's self-concept of social support's five components. The deaf children interact more with their peers in the school, both with the other deaf children and other children with disabilities in a language they understand. When in the home environment, children with hearing impairment communicate more with their peers who do not have disabilities or communicate with their siblings or siblings. It can occur because social contact between children with hearing impairment involves awareness and physical contact and an invitation to interaction. ${ }^{16}$ This also shows that deaf children will be more open to their friends and their siblings because they feel they are at the same age, so they feel more comfortable telling stories with friends and siblings rather than with their parents, families, and adults.

These results are in accordance with Erickson's psychosocial development concept that children aged 7-12 years tend to like peer interaction. This study shows that the social development of deaf children is the same as the development of children aged 7-12 years in general. It is just a disturbance in their hearing function. Communication and interaction used are different from normal children aged 7-12 years. ${ }^{17}$ This affects the existence of peer social support, which has a more significant influence on the self-concept of children with disabilities, one of which is deafness, compared to social support that comes from parents. ${ }^{12}$ Therefore, parents need to be good examples, befriends deaf children, pay attention, and be fair to children. Also, if necessary, parents learn sign language so they can better understand deaf children.

The self-concept of deaf children aged 7-12 years in SLB Jember Regency in this study had a low self-concept, namely $60.8 \%$. That result is in line with research that states that children with hearing impairment experience delays in language development resulting from early deprivation. The delay hinders deaf children from communicating with their social environment because they will find it difficult to hear and understand what is happening around them. ${ }^{2,18}$ Of course, it affects the interaction of deaf children in their social environment, so that deaf children have a lower self-concept about themselves in terms of communication than normal children.

In general, there is a relationship between social support and the self-concept of deaf children aged 7-12 years in SLB Jember Regency. On the other hand, the relationship is generally not strong. From the five components of social support, only two components are related to self-concept (social support from friends and social support for siblings). Meanwhile, the other three components (social support from parents, social support from siblings, and social support for adults) are not related to self-concept. So, we made a final result that the relationship between social support and the self-concept of deaf children aged 7-12 years in SLB Jember Regency is reversed. It was good social support leads to a low self-concept. 
These results can also be related to the characteristics of the respondents. The majority of children with hearing impairment in special schools in Jember Regency are diagnosed with deaf since birth and are severely deaf. In addition, the majority of parents can use sign language. With these various characteristics, parents are accustomed to having a child with hearing impairment. There is no specific support given to the child, so that the parents' social support for deaf children is lacking. The special school teacher also stated that not all parents practice communication for deaf children at home. It will undoubtedly affect the communication and socialization skills of deaf children.

Deaf children will quickly carry out their daily activities if parents want to understand them by giving examples and various alternatives that make deaf children do their daily activities happily without coercion. ${ }^{19}$ On the other hand, the adult social support component includes teachers in children's schools. The relationship between teachers and deaf children at school is limited in the classroom only. The deaf children spend time at school with their schoolmates during break time. In addition, the relationship between deaf children and siblings can be affected by the intensity of meeting deaf children with their siblings. It will affect the relationship between adult social support and sibling social support with the self-concept of children with hearing impairment.

\section{Conclusion}

Social support is related to the self-concept of deaf children aged 7-12 years in SLB Jember Regency ( $p$-value $=0.034)$. Deaf children with good social support had a low self-concept 1,833 times (OR = $1,833 ; 95 \% \mathrm{Cl}=1,400-2,401)$. On the other hand, the relationship is inversely proportional, such as children with hearing impairment who have high social support have a low self-concept. It is influenced by the fact that of the five components of social support, only two components, for instance social support from friends and social support for siblings, are related to self-concept. In comparison, for the other three components, social support for parents, social support for siblings, and social support for adults are not related self-concept of deaf children aged 7-12 years in SLB Jember Regency.

\section{Acknowledgement}

The Faculty of Nursing University of Jember as a place of study, special schools in Jember Regency who have been willing to be participants in this research, and the Family and Health Care Studies Research group which has facilitated this research.

\section{Conflict of interest}

There is no conflict of interest

\section{References}

1. Hasriani. Penerimaan diri (self-accaptance) pada penyandang tunarungu. Psiko Edukasi. 2018.

2. Mekonnen M, Hannu S, Elina L, Matt, K. The selfconcept of deaf/hard-of-hearing and hearing students. J. Deaf Stud. Deaf Educ. 2016;21:345351.

3. Theunissen SCPM, Rieffe C, Netten AP, Briaire JJ, Soede W, Kouwenberg $M$, et al. Self-esteem in hearing-impaired children: The influence of communication, education, and audiological characteristics. PLoS One. 2014;9(4):e94521.

4. Stuart GW. Keperawatan Kesehatan Jiwa. 2016. Elsevier.

5. Collins K. Walk the land in Malaysia. Glob. Burd. Dis. 2004 Updat. 2011;1-11.

6. Kementerian Kesehatan RI. Situasi Penyandang Disabilitas. 2014.

7. Pusat data dan Statistik Pendidikan dan Kebudayaan. Statistik Sekolah Luar Biasa (SLB). Kementeri. Pendidik. dan Kebud. Sekr. jenderal Pus. Data dan Stat. Pendidik. dan Kebud. RI. 2016.

8. Dinas Sosial Provinsi Jawa Timur. Penyandang Masalah Kesejahteraan Sosial Menurut Kabupaten/Kota, 2016.

9. Brice $P$, Strauss $G$. Deaf adolescents in a hearing world: a review of factors affecting psychosocial adaptation. Adolesc. Health. Med. Ther. 2016;7:67.

10. Octaviani, R. D. Deaf art community. 2015.

11. Gordon AT. Assessing social support in children: Development and initial validation of the social 
support questionnaire for children. Louisiana State Univ. LSU Digit. Commons. 2011;1-83.

12. Senicar M, Grum DK. Self-concept and social support among adolescents with disabilities attending special and mainstream schools. 2012; 48.

13. Jarmitia S. The Relationship between social support and self-confidence of person with physical disability in special education schools in. Psikoislamedia. 2016; 1:61-69.

14. Antia S, Kreimeyer KH, Metz K. Oxford handbooks online peer interactions of deaf and hard-ofhearing. Res. gate (2012).

15. Jalvia $L$. The role of siblings in the habilitation of families with children who are deaf or hard-of- hearing. 2009.

16. Lelyana MSL. Interaksi sosial antar anak tunarungu dan anak tunarungu dengan anak dengar. Universitas Sanata Dharma, Yogyakarta. 2019.

17. Potter PA, Perry AG. Fundamental Keperawatan: Konsep, Proses, dan Praktik. 2010. EGC.

18. Maurya R, Singh VK. A study of self-concept of hearing-impaired children in relation to their academic achievement. Int J Adv Educ Res. 2016;1:39-42.

19. Putri SS, Supena A, Yatimah D. Dukungan sosial orangtua anak tunarungu usia 11 tahun di SDN Perwira Kota Bogor. J Educ J Pendidik Indones. 2019;5:20. 